www.volsu.ru

DOI: http://doi.org/10.15688/nav.jvolsu.2017.1.8

UDC 903.53+904(351.853.3)(1-924.86)

LBC T63.4(2)235.7

\title{
MOKRYY IV BURIAL MOUND
}

\author{
Roman V. Prokofyev \\ Centre for Practical Archaeology, Rostov-on-Don, Russian Federation \\ Tatyana E. Prokofyeva \\ Centre for Practical Archaeology, Rostov-on-Don, Russian Federation
}

\begin{abstract}
The article is devoted to the publication of the excavation materials from the Mokryy IV burial mound, which is located on the right bank of the Lower Don. The barrow, which consists of two barrows, is situated between the Kadamovka and the Kertchik rivers at the top of the watershed of the Sukhaya and Mokraya hollows. The archaeological site was discovered by B.A. Raev in 1983. Barrow 2 was excavated by Yuzharkheologiya expedition in 2011. It consisted of a single robbed nomad medieval burial, surrounded by a circular ditch. Barrow 1 was explored by Rostov archaeological expedition group under our guidance in 2014. Four successive earthfills were fixated in the incisions of barrow 18, dated back to different periods, were explored. The earliest pre-barrow burials belongs to Eneolithic Era. The erection of the earthfill of the barrow is connected with the burial of late PitGrave (Yamnaya) - early Katakombnaya culture, which had almost been destroyed by later Katakombnaya burial and robbers of Modern Age. Next two earthfills are connected with the burials of Katakombnaya culture. There are 5 of them in the barrow in total. The last earthfill of the barrow was made at the turn of the middle-late Bronze Age for a burial of Babino culture. At least 6 burials of Srubnaya culture were made in the barrow in the late Bronze Age. And two more burials date back to early Iron Age. At the last stage 2 medieval oguz nomad burials were made in the barrow. The implements of the most burials are represented by various handmade jars. Few pieces of weapons, tacks and garment elements were found in the medieval burials.

Key words: the Lower Don, Eneolithic, late Pit-Grave (Yamnaya) culture, Katakombnaya culture, Babino culture, Srubnaya culture, Early Iron Age, medieval oguz nomads.
\end{abstract}

Citation. Prokofyev R.V., Prokofyeva T.E., 2017. Mokryy IV Burial Mound. The Lower Volga Arhaeological Bulletin, vol. 16, no. 1, pp. 125-142. (in Russian).

УДК 903.53+904(351.853.3)(1-924.86)

ББК Т $63.4(2) 235.7$

\section{КУРГАННЫЙ МОГИЛЬНИК «МОКРЫЙ IV»}

Роман Викторович Прокофьев

ООО «Центр Практической Археологии», г. Ростов-на-Дону, Российская Федерация

\section{Татьяна Евгеньевна Прокофьева}

ООО «Центр Практической Археологии», г. Ростов-на-Дону, Российская Федерация

Аннотация. Статья посвящена публикации материалов раскопок курганного могильника «Мокрый IV» на правобережье Нижнего Дона. Могильник, состоящий из двух курганов, расположен в междуречье рек Кадамовка и Керчик, на вершине водораздела балок Сухая и Мокрая. Памятник открыт в 1983 г. Б.А. Раевым. В 2011 г. экспедицией Южархеологии был раскопан курган 2. Он содержал единственное ограбленное средневековое кочевническое погребение, окруженное кольцевым ровиком. Курган 1 исследовался в 2014 г. отрядом Ростовской археологической экспедиции под нашим руководством. В бровках кургана зафиксировано наличие четырех последовательных досыпок. Всего в кургане было исследовано восемнадцать разновременных погребений. Наиболее раннее, докурганное, погребение относится к эпохе энеолита. Возведение земляной насыпи кургана связано с погребением позднеямной - раннекатакомбной культуры, впоследствии практически полно- 
стью разрушенным более поздним катакомбным погребением и грабителями нового времени. Две последующие досыпки связаны с погребениями катакомбной культуры, общее количество которых в кургане составляет пять. Последняя досыпка кургана была осуществлена на рубеже эпох средней - поздней бронзы при совершении погребения бабинской культуры. В эпоху поздней бронзы в курган было впущено не менее шести погребений срубной культуры, а в раннем железном веке - еще два. На завершающей стадии в кургане были совершены два средневековых кочевнических погребения, принадлежащие огузам. Инвентарь большинства погребений составляли разнообразные лепные сосуды. В средневековых погребениях найдены немногочисленные предметы вооружения и конской упряжи, детали костюма и принадлежности бытового обихода.

Ключевые слова: Нижний Дон, энеолит, позднеямная культура, катакомбная культура, бабинская культура, срубная культура, ранний железный век, средневековые кочевники огузы.

Цитирование. Прокофьев Р. В., Прокофьева Т. Е., 2017. Курганный могильник «Мокрый IV» // Нижневолжский археологический вестник. Т. 16, № 1. С. 125-142.

Курганный могильник «Мокрый IV», состоящий из двух насыпей, выявлен в 1983 г. разведкой Б.А. Раева при подготовке паспортов на памятники археологии Октябрьского района Ростовской области. Могильник расположен в междуречье Кадамовки и Керчика, двух небольших правобережных донских притоков, в 3,2 км к ЗЮЗ от хут. Первомайский. Памятник занимает западный край плоского гребня водораздела правого борта балки Сухая и левого борта балки Мокрая, впадающих в Кадамовку слева.

Оба кургана могильника были исследованы в связи со строительством магистрального газопровода «Южный поток».

В 2011 г. НП «Южархеология» был раскопан курган 2 диаметром 25 м и высотой 0,3 м. Исследовано единственное ограбленное средневековое кочевническое погребение в подбое, окруженное кольцевым ровиком. Человеческое захоронение сопровождалось чучелом коня (череп и кости ног) и костями ног барана. В инвентаре - обломки железного стержня плохой сохранности и фрагментированный лепной сосуд [Гудименко, Цыбрий, 2011].

В 2014 г. ООО «Ростовская археологическая экспедиция» был раскопан курган 1 диаметром 38 м и высотой 1,4 м. Насыпь уплощенно-полусферической формы, в центре остатки разрушенного триангуляционного знака с отметкой 102,2 по Балтийской системе высот. Восточная половина кургана распахивается, западная, расположенная в лесополосе, густо поросла травой, кустарником и мелким подлеском.

В северном фасе центральной бровки кургана зафиксировано следующее расположение слоев (рис. 1,4).
1. Задернованный лесной гумус - рыхлый мелкокомковатый черный гумусированый суглинок с корнями деревьев.

2. Пахотный слой - плотный, в верхнем горизонте крупнокомковатый, темно-серый гумусированый суглинок.

3. Современная почва - рыхлый серый гумусированый суглинок.

4. II насыпь - комковатый светло-серый гумусированый суглинок с белесыми высолами, особенно интенсивными по краям.

5. I насыпь - плотный темно-серый гумусированый суглинок.

6. Выкид погребения 5 - материковый суглинок.

7. Предматерик - плотный коричневатосветло-серый слабогумусированый суглинок.

8. Материк - плотный коричневато-оранжевый суглинок с крупными белесыми карбонатными включениями.

Описанный стратиграфический разрез достаточно информативен, но не полностью отражает картину сооружения кургана. В других бровках (рис. 1,3,5) удалось зафиксировать еще две насыпи, что дает право утверждать, что курган был сооружен в четыре приема: I насыпь связана с погребением 5, II с погребением 16, III - с погребением 11, IV с погребением 9.

Всего в кургане было исследовано 18 погребений, 15 ситуаций и следы грабежа, сильно повредившего центральную часть кургана (рис. 1,2). Датировка грабежа определяется находками обломков поливной «казачьей» керамики и фарфоровых чашек фабрики И.Е. Кузнецова на Волхове 1878-1880 годов.

Среди ситуаций следует отметить несколько наиболее интересных: ситуации 2 и 3 - 
фрагментированные лепные сосуды баночной формы, относящиеся к срубной культуре (рис. 2,1-2); ситуация 8 - группа крупных и мелких камней за пределами насыпи (рис. 1,2); ситуация 10 - втулка бронзового наконечника стрелы с коротким шипом (рис. 2,4); ситуация 12 - фрагментированный лепной сосуд, покрытый сплошным орнаментом, относящийся к позднеямному-раннекатакомбному времени (рис. 2,3); ситуация 14 - фрагменты двух лепных сосудов катакомбной культуры, один из которых покрыт веревочным орнаментом (рис. 2,5); ситуация 15 катакомбной культуры - лепной орнаментированный тесьмой сосуд (рис. 2,7), жаровня из верхней части крупного лепного сосуда, орнаментированного налепным валиком (рис. 2,6), и каменный растиральник округлой формы (рис. 2,8).

Погребение 1. Впускное, раннего железного века (?). Могильная яма не прослежена. Погребенный подросток 12-15 лет ${ }^{1}$ располагался вытянуто на спине, головой на СС3 (рис. 2,9). Инвентарь в погребении отсутствовал.

Погребение 2. Впускное, срубной культуры. Могильная яма не прослежена. Погребение сильно разрушено. Судя по сохранившимся костям, погребенная женщина (?) старше 30 лет была положена скорченно на левом боку, головой на В (рис. 2,10). Инвентарь в погребении отсутствовал.

Погребение 3. Впускное, срубной культуры. Могильная яма не прослежена. Погребение сильно разрушено. Судя по сохранившимся костям, погребенный ребенок 8-10 лет был положен скорченно на боку, головой на В (рис. 2,11).

Инвентарь:

1. Юго-восточнее тазовой кости погребенного на дне устьем вверх стоял лепной сосуд горшковидной формы. Верхняя часть сосуда утрачена. Д ${ }^{\mathrm{T}}-15,0 \mathrm{~cm}$, ДД $-10,4 \mathrm{~cm}$, сохранившаяся $\mathrm{H}-9,5$ см (рис. 2,12) ${ }^{2}$.

2. Внутри сосуда найдены мелкие стержневидные обломки бронзового изделия.

3. Под тазовой костью погребенного лежали два астрагала со сточенными боковыми поверхностями (рис. 2,13).

Погребение 4. Впускное, срубной культуры. Могильная яма не прослежена. Погре- бение практически полностью разрушено при сооружении погребения 10. От костяка погребенного подростка 15-17 лет сохранились лишь фрагменты бедренной, большой и малой берцовых костей левой ноги в сочленении, судя по которым погребенный был положен скорченно на левом боку, головой на В (рис. 3,1).

В заполнении погребения найдены фрагменты, в том числе дна, лепного сосуда (рис. 3,2).

Погребение 5. Основное, позднеямной - раннекатакомбной культуры. Могильная яма не прослежена. Остатки погребения, разрушенного при сооружении погребения 15 и, возможно также, при грабеже кургана в новое время, зафиксированы на дне входного колодца погребения 15. От костяка погребенной взрослой женщины (?) сохранились лишь левая коленная чашечка, берцовые кости и кости стоп обеих ног в сочленении, посыпанные красной охрой. Судя по этим костям, погребенная была положена головой на 3 , с подогнутыми вправо ногами (рис. 3,3). Инвентарь в погребении отсутствовал.

Погребение 6. Впускное, срубной культуры. Могильная яма не прослежена. Погребение частично разрушено. Верхняя часть костяка утрачена. Судя по сохранившимся костям, погребенный мужчина старше 35 лет был положен скорченно на левом боку, головой на В (рис. 3,5).

Южнее коленного сустава левой ноги погребенного найдены фрагменты, в том числе дна, лепного сосуда (рис. 3,4).

Погребение 7. Впускное, срубной культуры. Могильная яма не прослежена. Погребение сильно разрушено. Фрагменты черепа смещены относительно своего естественного положения. Судя по сохранившимся костям, погребенный взрослый мужчина был положен скорченно на левом боку, головой на В (рис. 3,6).

В заполнении погребения найдены фрагменты, в том числе венчика, лепного сосуда баночной формы (рис. 3,7 ).

Погребение 8. Впускное, средневековое, огузское. На верхнем уровне фиксации контур могильной ямы еще не прослеживался. В западной части погребения был обнаружен череп коня, обращенный мордой к 3. Во- 
сточнее от черепа - конское копыто и сустав ноги, кости которой уходили вглубь заполнения. Южнее черепа коня лежали 2 позвонка, а в 0,3 м к востоку от них - обломок плечевой кости молодой женщины. Помимо этого, на верхнем уровне фиксации в погребении были встречены отдельные разрозненные обломки костей животных (рис. 3,8 ).

С верхним уровнем фиксации связаны следующие находки:

1. При разборке черепа коня найдены фрагменты железных удил - округлое в сечении трензельное кольцо с небольшим обломком прикипевшего к нему кольцевого окончания стержня грызел и их более мелкие фрагменты. Диаметр кольца 3,8 см, сечение 0,60,9 см (рис. 4,14).

2. В заполнении у черепа коня найден фрагмент черешка железного ножа. Сечение: $0,5 \times 0,3 \mathrm{~cm}$, сохранившаяся длина $1,7 \mathrm{~cm}$ (рис. 4,7).

3. Южнее черепа коня лежала свинцовая ворворка усеченно-конической формы с цилиндрическим возвышением в центре верхней стороны. Ворворка украшена рельефным орнаментом в виде кольцевого бортика по периметру и радиально-лучевых линий от центрального отверстия к краям изделия, между которыми находятся небольшие полусферические бугорки. Диаметр ворворки 2,4 см, высота 1,0 см, диаметр отверстия 0,65 см (рис. 4,1 ).

Подобные предметы трактуются также как пряслица или грузики-пломбы и являются одним из характерных элементов погребального обряда огузов [Круглов, 2001, с. 399].

4. Восточнее конского копыта найден фрагмент овального в сечении $(0,6 \times 0,5 \mathrm{~cm})$ железного гвоздя (рис. 4,12).

5. Восточнее черепа коня лежали фрагменты лепного сосуда баночной формы срубной культуры. Реконструируемые размеры: $Д^{\mathrm{B}}-14,9$ см, $Д^{\mathrm{T}}-15,6$ см. Сохранившаяся $\mathrm{H}-$ 12,3 см (рис. 3,12 ).

6. Севернее конского копыта внутренней стороной вверх лежала жаровня из верхней части лепного сосуда катакомбной культуры. По шейке сосуд орнаментирован неровным тройным горизонтальным рядом вертикальных ногтевых вдавлений, местами прерывающимся двойным вертикальным рядом из горизонтальных ногтевых оттисков. Средняя часть венчика и тулово ниже орнамента покрыты группами наклонных расчесов (рис. 3,10).

На нижнем уровне фиксации после съема находок верхнего уровня горизонтальной зачисткой было выявлено пятно заполнения могильной ямы погребения. Могильная яма неправильной подпрямоугольной формы с крупным треугольным выступом в средней части северной стенки, длинной осью ориентирована по линии 3-В (рис. 3,9). Погребенная женщина 35-40 лет была положена на дне, по центру могильной ямы вытянуто на спине, головой на 3. Поверх правой бедренной и нижних концов берцовых костей обеих ног погребенной лежали кости четырех конечностей коня с копытами, отчлененные по пястный сустав. Лошадь полутонконогая, среднерослая, высотой в холке 136-144 см, возрастом старше 3-4 лет. На ребрах левой части грудной клетки и у правого тазобедренного сустава погребенной прослеживался белесый мелковолокнистый тлен, а местами под костяком на дне могильной ямы пятна коричневого тлена. В заполнении могильной ямы встречались мелкие куски дерева - вероятно, остатки перекрытия. При разборке под черепом погребной была найдена верхняя половина правой бедренной кости взрослого мужчины.

Инвентарь:

1. Южнее черепа погребенной острием к С3 лежал железный нож с остатками деревянных ножен. Овальная в сечении деревянная рукоять ножа была плотно оплетена витой тонкой серебряной проволокой. Оплетка производилась не одинарной, а сдвоенной проволокой с противоположным направлением скрутки, в результате чего оплетка приобрела елочный, или косичкообразный, орнамент. Окончание проволоки у торца рукояти выполнено в виде короткого гвоздика с округлой головкой, фиксировавшего оплетку на деревянной основе. Длина черешка $4,7 \mathrm{~cm}$, сечение $0,75 \times 0,15$ см. Длина клинка 6,4 см, сечение$1,1 \times 0,6$ см. Сечение рукояти $-1,25 \times 0,9$ см. Толщина проволоки оплетки $-0,05$ см (рис. 4,11).

Идентичная серебряная оплетка рукояти встречена на ноже из кургана 39 кочевни- 
ческого могильника Саркела - Белой Вежи [Плетнева, 1963, с. 225-226, 251, рис. 24,2]. Датировка могильника не выходит за рамки конца IX - XI в., а его этнический состав характеризуется значительным количеством погребений торков-огузов [Плетнева, 1963, c. 258-259].

2. Среди ребер грудной клетки погребенной под белесым мелковолокнистым органическим тленом найдены бронзовые пуговицы-«бубенчики» (5 ед.). Половинка и три целых «бубенчика» находились в левой половинегрудной клетки. Вторая половинка и еще одна целая пуговица лежали справа в нижней части рудной клетки, вероятнее всего в перемещенном состоянии. Пуговицы изготовлены методом штамповки из тонкого бронзового листа. «Бубенчики» полые, сферической формы, с небольшой овальной петелькой для подвешивания. Состоят из двух симметричных половинок, соединенных по вертикальной оси изделия, каждая из половинок с ушком. Размеры всех пуговиц довольно близки: $2,55 \times 1,9 \times 1,85 ; 2,55 \times 1,9 \times 1,85 ; 2,55 \times 1,85 \times 1,85$; $2,6 \times 1,85 \times 1,85$ и $2,65 \times 1,8 \times 1,75$ см (рис. $4,2-0$ ).

3. Поверх правого тазобедренного сустава погребенной лежали коррозированные сильно фрагментированные железные шарнирные ножницы (рис. 4,8-10). Лезвия ножниц в сечении широкие, уплощенные $(2,2 \times 1,0$ см). Рукояти более массивные, овально-подпрямоугольные $(1,2 \times 1,1 \mathrm{~cm})$. На одном из фрагментов прослежены остатки пропитанной окислами железа ткани прямого плетения (рис. 4,10).

4. Под железными ножницами среди фаланг пальцев правой руки погребенной найдены металлические и стеклянные детали игольника (?):

- широкая бронзовая обойма округлой кольцевидной формы, ее размеры: $1,6 \times 1,4 \times 0,8 \mathrm{~cm}$, толщина пластины 0,05 см (рис. 4,15);

- плоская бронзовая пластина округлой формы со следами кольцевого припоя по окружности, которым пластина крепилась к вышеописанной широкой бронзовой обойме, диаметр пластины 1,8 см, толщина 0,05 см (рис. 4,16);

- плоская округлая бронзовая пластина, аналогичная ранее описанной, но чуть меньшего диаметра; изделие распалось при реставрации;

- мельчайшие обрывки тонкой серебряной фольги и тонкой витой серебряной прово- локи, покрывавшие снаружи ранее описанную широкую бронзовую обойму;

- стеклянные вставки-накладки (4 ед.).

Поверх округлой плоской бронзовой пластины лежала крупная, округлая, поперечно уплощенная вставка коричневого полупрозрачного стекла. Нижняя плоскость с вмятиной, образовавшейся в результате выкладывания еще горячего стекла на неровную поверхность. Размеры: 1,65 × 1,5 × 0,7 см (рис. 4,17).

По бокам от широкой бронзовой обоймы, частично окруженные серебряной фольгой, лежали три вставки меньшего размера, неправильной округленной формы. Две из них изготовлены из коричневого полупрозрачного стекла, а одна - из бирюзового полупрозрачного стекла. Размеры: $0,55-0,65 \times 0,45-0,5$ см (рис. 4,18-20).

Обнаруженные элементы могли составлять детали игольника. Предположительно он может быть реконструирован в виде цилинд$\mathrm{pa}$, сшитого из одного куска плотной кожи, держащей форму. Округлая бронзовая пластина меньшего диаметра служила дном игольника. Спаянные между собой бронзовые обойма и округлая пластина большего диаметра составляли его крышку. Крышка декорировалась стеклянными накладками - одной крупной верхней и тремя мелкими боковыми. Бронзовая обойма была обтянута тонкой серебряной фольгой с гнездами для стеклянных вставок, крепившейся при помощи оплетки тонкой витой серебряной проволоки, аналогичной оплетке рукояти ножа (рис. 3,11).

5. Между костями ног коня лежал фрагмент железного гвоздя (рис. 4,13).

Погребение 9. Основное для насыпи IV, бабинской культуры. Могильная яма подовальной формы, длинной осью ориентирована по линии 3-В. Погребение сильно разрушено. Большая часть костяка отсутствует. Судя по сохранившимся костям, погребенная женщина 25-30 лет была положена на дне по центру могильной ямы в слабо скорченном положении на правом боку, головой на 3. Сохранившиеся берцовые кости и нижняя челюсть погребенной посыпаны красной охрой. Отдельный комок охры был найден на дне могильной ямы южнее черепа погребенной. За черепом лежали обломки деревянных плашек. Аналогичные плашки встречались и в 
заполнении могильной ямы. Вплотную к черепу погребенной лежал фрагментированный череп ребенка возрастом до 5 лет (рис. 5,1).

Инвентарь:

1. Под черепом погребенной при разборке костяка найдено бронзовое шило. Размеры: $6,1 \times 0,3 \times 0,3$ см (рис. 5,2).

2. В заполнении могильной ямы найден фрагмент стенки орнаментированного веревочкой лепного сосуда (рис. 5,3).

Погребение 10. Впускное, катакомбной культуры. Могильная яма предположительно имела катакомбную конструкцию. На дне по центру камеры лицевой частью вниз лежал череп мужчины 30-35 лет (рис. 5,6).

Инвентарь:

1. Восточнее черепа погребенного на дне при переходе колодца в камеру лежал фрагмент стенки лепного реповидного сосуда, орнаментированного налепным валиком. Еще 5 фрагментов этого же сосуда происходят из заполнения могильной ямы (рис. $5,4,7$ ).

2. В заполнении могильной ямы найден фрагмент стенки лепного сосуда с орнаментом, относящийся, вероятно, к срубной культуре (рис. 5,5).

Погребение 11. Основное для насыпи III, катакомбной культуры. Могильная яма подквадратной с широко скругленными углами формы, стенками ориентирована по сторонам света. В заполнении восточной части могильной ямы в 0,7 м выше уровня дна найден лежащий на основании череп с крупными рогами быка домашнего возрастом старше 34 лет, мордой обращенный к Ю3 (рис. 5,8).

Кроме того, в заполнении могильной ямы были найдены кости овцы или козы домашней и разрозненные фрагменты придонной части лепного сосуда катакомбной культуры. ДД-10,2 см (рис. 5,9).

Погребение 12. Впускное, срубной культуры. Могильная яма не прослежена. Погребение сильно разрушено при сооружении погребения 13. Судя по сохранившимся костям, погребенная женщина возрастом старше 30 лет была положена скорченно на левом боку, головой на В (рис. 5,10). В заполнении погребения встречена кость черепа ребенка.

Западнее фрагмента черепа погребенной устьем вверх стоял фрагментированный лепной орнаментированный сосуд. $Д^{\mathrm{B}}-20,2$ см,
$Д^{\mathrm{T}}-23,0$ см, ДД-11,4 см, Н $-14,8$ см (рис. 5,11).

Погребение 13. Впускное, средневековое огузское. Могильная яма не прослежена. Верхнюю часть костяка погребенного перекрывал череп коня, уложенный на левый бок, мордой к 3 (рис. 5,12). Лошадь средненогая, среднерослая, высотой в холке 136-144 см, возрастом старше 3-4 лет. Погребенный мужчина 25-30 лет был положен вытянуто на спине, головой на 3. Берцовые кости обеих ног погребенного отсутствуют. У правого тазобедренного сустава и частично поверх костей правого предплечья погребенного были положены две ноги коня с копытами, отчлененные по пястный сустав. Вторая пара конечностей коня, также отчлененных по пястный сустав, была расчищена в восточной части погребения. Под этими костями находились кости стоп погребенного. В заполнении погребения были встречены разрозненные кости мужчины (?) 25-35 лет и ребенка, вероятно, относящиеся к частично разрушенному погребению 12.

Инвентарь:

1. В пасти коня находились фрагментированные железные удила. Сохранились оба округлых в сечении трензельных кольца, на которые надеты загнутые в кольца концы стержня грызел. Диаметр трензельных колец 4,2 и 4,5 см, сечение 0,9 cм (рис. 6,17-18).

2. Поверх левого крыла таза и нижней части грудной клетки погребенного лежал сильно фрагментированный колчан из плохо сохранившегося органического материала, длинной осью ориентированный по линии СВЮ3. Верхнюю торцевую стенку колчана составляла широкая костяная пластина. Местами вдоль длинных стенок колчана прослеживались окислы от его мелких железных деталей. В камеральных условиях удалось выделить следующие элементы:

- костяные детали: широкие пластины имеют ровную гладкую нижнюю сторону и чуть выпуклую, также заглаженную внешнюю, снабжены небольшими округлыми отверстиями для железных заклепок. На верхней стороне узкой пластины прослежены частые легкие наклонные бороздки (потертость ремнем?) и едва намеченный единичный элемент циркульного орнамента (рис. 6,2-5); 
- железные детали: Г-образная изогнутая овальная в сечении железная пластина; железная заклепка с широкой округлой шляпкой, предположительно крепившая широкие костяные пластины колчана; два обломка плоских Т-образных головок небольших округлых или подтреугольных в сечении гвоздиков; обломки различных в сечении стержневидных предметов - гвоздей или ребер жесткости каркаса колчана (рис. 6,7-13).

3. В верхней части колчана острием к Ю3, то есть вверх по отношению к костяку погребенного, лежали 3 железных наконечника стрел. Все они однотипные - двухлопастные черешковые. Размеры головок: $6,9 \times 2,8 \times 0,7 ; 6,5 \times 2,8 \times 0,7$ и $6,5 \times 2,7 \times 0,8$ см. Сохранившаяся полная длина черешка $5,7 \mathrm{~cm}$, максимальный диаметр 0,8 см (рис. 6,14-10).

4. С внутренней стороны у середины левой бедренной кости погребенного найден обломок железного ножа (рис. 6,6).

5. В заполнении погребения встречен фрагмент стенки лепного сосуда с врезным волнистым орнаментом (рис. 6,1).

Найденный фрагмент находит аналогии в группе лепной кочевнической керамики Саркела [Плетнева, 1959, с. 230-239, рис. 15,1$2,4-6 ; 18,10 ; 19,9,11-13,15,18-19 ; 23,2]$.

Поза и ориентировка погребенного в сочетании с сопровождающим захоронением чучела коня над ним, отмеченные для погребения 13 и ранее описанного погребения 8, являются одной из выразительных черт, характеризующих погребальный обряд средневековых кочевников-огузов [Гарустович, Иванов, 2001, с. 66-94; Круглов, 2003].

Погребение 14. Впускное, раннего железного века (?). Могильная яма не прослежена. Погребение сильно разрушено при установке глубоко вкопанного бетонного основания геодезического репера. Погребенная взрослая женщина была положена вытянуто на животе, головой на $3 Ю 3$ (рис. 7,1). У кисти левой руки погребенной прослежено овальное пятно коричневого (древесного?) тлена, на котором лежали фрагменты тазовых костей и бедренной кости овцы или козы домашней. Кроме того, в заполнении погребения были найдены фрагменты большеберцовой и тазовой кости подростка 14-16 лет. Инвентарь в погребении отсутствовал.
Погребение 15. Впускное, катакомбной культуры. Могильная яма катакомбной конструкции. На дне под восточной стенкой входного колодца расчищены кости ног человека погребения 5, разрушенного при устройстве описываемого погребения. Погребенный ребенок 7-8 лет был положен на дне по центру камеры скорченно на правом боку с завалом на спину, головой к Ю. На дне камеры частично под туловищем погребенного прослежено пятно светло-желтого органического тлена. Местами на костяке и на дне камеры наблюдались мелкие пятна яркокрасной киновари (рис. 7,2). В заполнении входного колодца были встречены разрозненные кости мужчины 25-35 лет и подростка 15-17 лет.

Инвентарь.

1. В заполнении входного колодца были найдены:

- фрагмент стенки лепного сосуда;

- фрагменты лепного реповидного сосуда, орнаментированного налепными валиками с пальцевыми вдавлениями - горизонтальным по плечику и радиально-лучевыми на внутренней стороне плоскости дна (рис. 7,3-б);

- дужка бронзового перстня. Судя по относительно хорошей сохранности металла, перстень может относиться к новому времени и принадлежать одному из грабителей (рис. 7,8 );

- половинка округлой полихромной бусины, изготовленной из черного непрозрачного стекла, орнаментированного 4 рядами поперечных фестонов. Диаметр - 1,6 см, длина $1,6 \mathrm{~cm}$ (рис. 7,9).

Бусина относится к раннему железному веку и может быть датирована IV-III вв. до н. э. или III в. н. э. [Алексеева, 1978, с. 48].

2. В заполнении восточной части входного колодца в 0,9 м выше дна и у его южного края найдены фрагменты лепной орнаментированной веревочным штампом курильницы. $Д^{\mathrm{B}}-17,2$ см, ширина основания $-8,4$ см, Н7,3 см (рис. 7,11).

3. В 0,2 м к ЮЮВ от черепа погребенного на дне у южной стенки камеры ножками вверх лежала еще одна лепная орнаментированная курильница. Внутри кармашка присутствовал светло-серый золистый тлен, а на внутренней поверхности чаши прослеживались следы нагара. Курильница орнаментиро- 
вана веревочным штампом. ДВ - 18,0 см, ширина основания $-7,4 \mathrm{~cm}, \mathrm{H}-8,0$ см (рис. 8,1 ).

4. Южнее черепа погребенного под югозападной стенкой камеры на боку лежал лепной неорнаментированный сосуд горшковидной формы. В придонной части сосуда содержался слой светло-желтого тлена. ДВ $12,3 \mathrm{~cm}, Д^{\mathrm{T}}-15,8 \mathrm{~cm}, Д^{Д}-8,8 \mathrm{~cm}, \mathrm{H}-11,7 \mathrm{~cm}$. Объем сосуда 1,15 л (рис. 7,7).

5. На лобной кости, по бокам и под черепом погребенного найдены костяные пронизи (24 ед.), вероятно, украшавшие головную повязку. Пронизи изготовлены из тонких трубчатых костей. Поверхность и торцы тщательно заглажены, местами до блеска. Размеры от $0,6 \times 0,6 \times 0,6$ до $1,65 \times 0,7 \times 0,55$ см (рис. 7,10).

Погребение 16. Основное для II насыпи, катакомбной культуры. Могильная яма катакомбной конструкции. На дне в западной части могильной ямы прослежено несколько отдельных пятен белесого тлена. Местами под ним присутствовал рыхлый зеленовато-светло-коричневый волокнистый тлен. На наиболее крупном пятне белесого тлена отмечены мелкие древесные угольки и посыпка красной охрой. На этом пятне и неподалеку от него найдены разрозненные кости человека, по которым позу и ориентировку погребенного восстановить не представляется возможным (рис. 8,2). В камеральных условиях антропологом установлено, что кости из заполнения могильной ямы и с ее дна относятся к трем костякам: женщины 25-35 лет, молодого человека и ребенка.

В заполнении погребения найдены фрагменты лепного реповидного сосуда, орнаментированного налепным валиком (рис. 8,3).

Погребение 17. Впускное, катакомбной культуры. Могильная яма не прослежена. Погребение сильно разрушено. Поза и ориентировка погребенного не восстанавливаются. В центральной части располагался фрагментированный череп ребенка 5-7 лет. Вплотную к СВ от него прослежено пятно желтого тлена, в южной, ближней к черепу части, посыпанное красной охрой. К востоку от желтого тлена отмечено небольшое овальное пятно коричневого тлена (рис. 8,5).

Юго-восточнее черепа погребенного устьем вверх стоял лепной сосуд. Сохранилась только его нижняя часть. ДД- $11,0 \mathrm{~cm}, \mathrm{H}-$ 8,5 см (рис. 8,4).

Погребение 18. Первоначальное, бескурганное, эпохи энеолита. Могильная яма удлиненно-овальной формы, длинной осью ориентирована по линии С-Ю. Погребенный младенец был положен вытянуто на спине, головой на Ю. Руки и ноги вытянуты. Под костяком погребенного на дне в северной половине могильной ямы прослежен белесый тлен, а в южной - посыпка красной охрой. Местами на белесом тлене и на дне могильной ямы встречались мелкие древесные угольки. Юго-восточнее черепа погребенного лежал отдельный комок ярко-красной охры (рис. 8,6).

Инвентарь:

1. Вплотную к Ю от черепа погребенного лежали мелкие фрагменты стенки лепного сосуда. Тесто рыхлое, слоистое, с примесью мелкодробленой ракушки. Внутренняя поверхность серая, черепок в изломе светло-коричневый. Подобный состав формовочной массы характерен для керамики эпохи энеолита.

2. Вплотную к ЮЗ от керамики лежала створка речной раковины.

$$
* * *
$$

Проведенные раскопки показали, что на естественном возвышении в месте будущего кургана 1 могильника «Мокрый IV» первым было совершено грунтовое энеолитическое погребение 18.

Возведение первоначальной земляной насыпи кургана связано с погребением 5 рубежа эпох ранней и средней бронзы. Позднее это погребение оказалось практически полностью разрушенным более поздним катакомбным захоронением 15 и грабителями нового времени. Вероятно, к инвентарю этого первого курганного захоронения следует отнести орнаментированный лепной сосуд, зафиксированный в качестве ситуации 12 .

Две последующие досыпки кургана были совершены уже в среднем бронзовом веке племенами - носителями катакомбной культуры. Представляется, что сначала в связи с совершением погребения 16 насыпь кургана была значительно увеличена в размерах (II насыпь). В эту уже увеличенную 
насыпь были впущены еще 3 захоронения катакомбной культуры - погребения 10, 15 и 17. С последним из них, вероятно, связаны остатки лепных сосудов, зафиксированных в качестве ситуации 14. Затем у юговосточного края полы кургана был устроен ритуальный комплекс, представленный обширным погребением 11 без костяка человека, но с черепом быка, и ситуацией 15 вероятными остатками поминальной тризны в составе лепного сосуда, жаровни и каменного орудия у внешнего края выкида из этого погребения. По завершении ритуальных действий комплексы и весь юго-восточный сектор кургана были засыпаны землей (III насыпь).

На финальном этапе эпохи средней бронзы в южный сектор кургана было впущено погребение 9 бабинской культуры. В связи с этим погребением в юго-западном секторе кургана была осуществлена очередная досыпка, придавшая кургану более симметричные очертания (IV насыпь).

В окончательно сформированную насыпь в последующую эпоху поздней бронзы были впущены как минимум 6 захоронений срубной культуры - погребения 2-4, 6-7 и 12. Еще 3 комплекса (ситуации 2-4) могут быть остатками тризн или относиться к разрушенным погребениям той же поры.

В раннем железном веке в кургане было совершено еще 2 погребения - 1 и 14. Втул- ка бронзового наконечника стрелы (ситуация 10) и обломок стеклянной полихромной бусины из заполнения погребения 15 могут относиться как к частично разрушенному погребению 14, так и принадлежать еще одному полностью разрушенному грабителями захоронению раннего железного века.

Вероятность того, что одно или несколько погребений оказались полностью разрушены грабителями, подтверждается находками разрозненных обломков костей человека в центре кургана (грабеж и ситуации 5-6). Скопления камней, зафиксированные в грабеже, могли составлять заклад входного отверстия катакомбы погребения 15 или перекрытие полностью разрушенного погребения срубной культуры. Попутно отметим, что камни ситуации 8 на дальней восточной периферии кургана, вероятно, являлись остатками заготовленного, но не востребованного в процессе совершения погребения строительного материала.

На завершающей стадии функционирования кургана в качестве кладбища в нем были совершены два, скорее всего синхронных средневековых огузских погребения, частично разрушившие несколько более ранних комплексов катакомбной и срубной культур. С этими средневековыми захоронениями могут быть связаны находки стенок причерноморских и трапезундских амфор из насыпи кургана и ситуаций 1 и 7. 


\section{ИЛЛЮСТРАЦИИ}

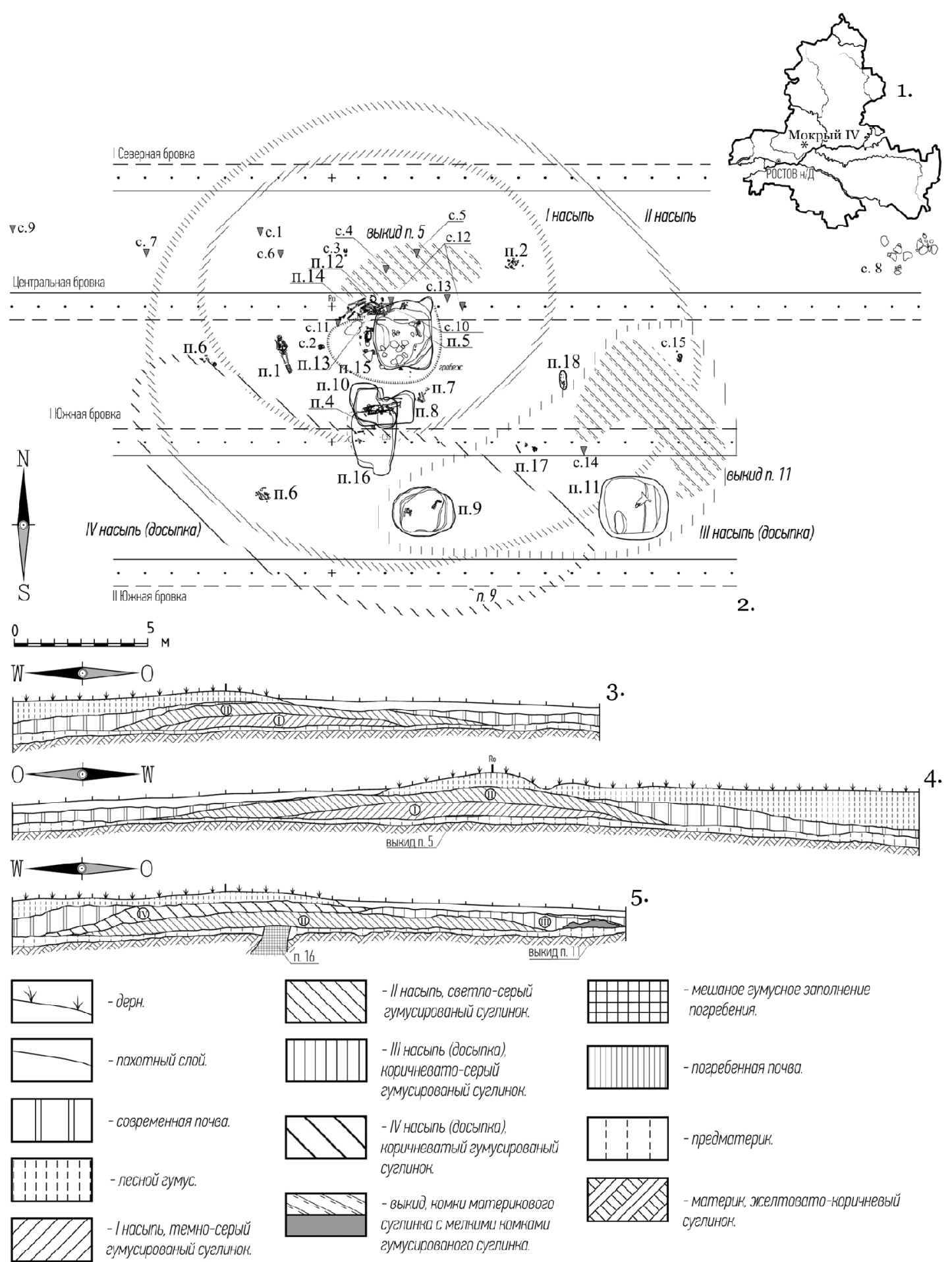

Рис. 1. Курганный могильник «Мокрый IV»:

1 - местоположение; 2 - план кургана 1; 3 - южный фас I северной бровки кургана 1; 4 - северный фас центральной бровки кургана $1 ; 5$ - южный фас I южной бровки кургана 1

Fig. 1. Mokryy IV burial mound:

1 - location; 2 - plan of barrow 1; 3 - barrow 1, southern face of the I Northern baulk; 4 - barrow 1, northern face of the Central baulk; 5 - barrow 1, southern face of the I Southern baulk 

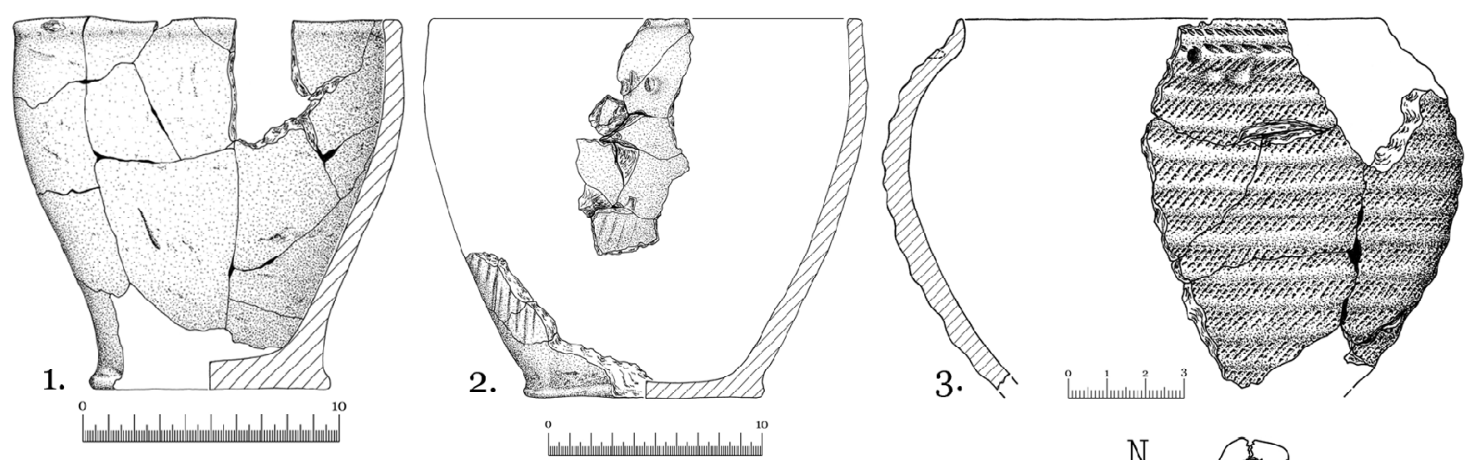

4 .
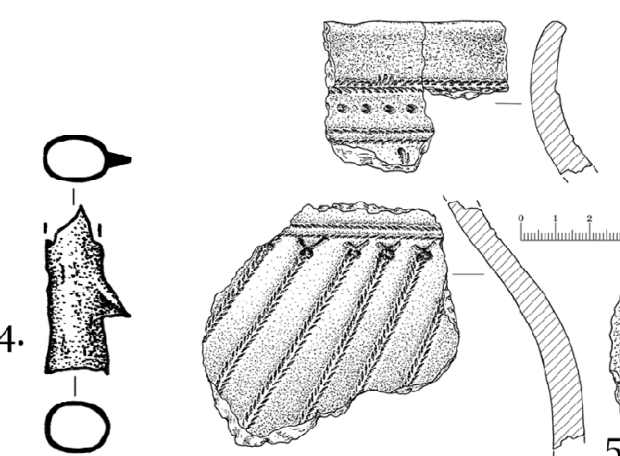

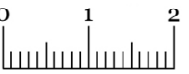
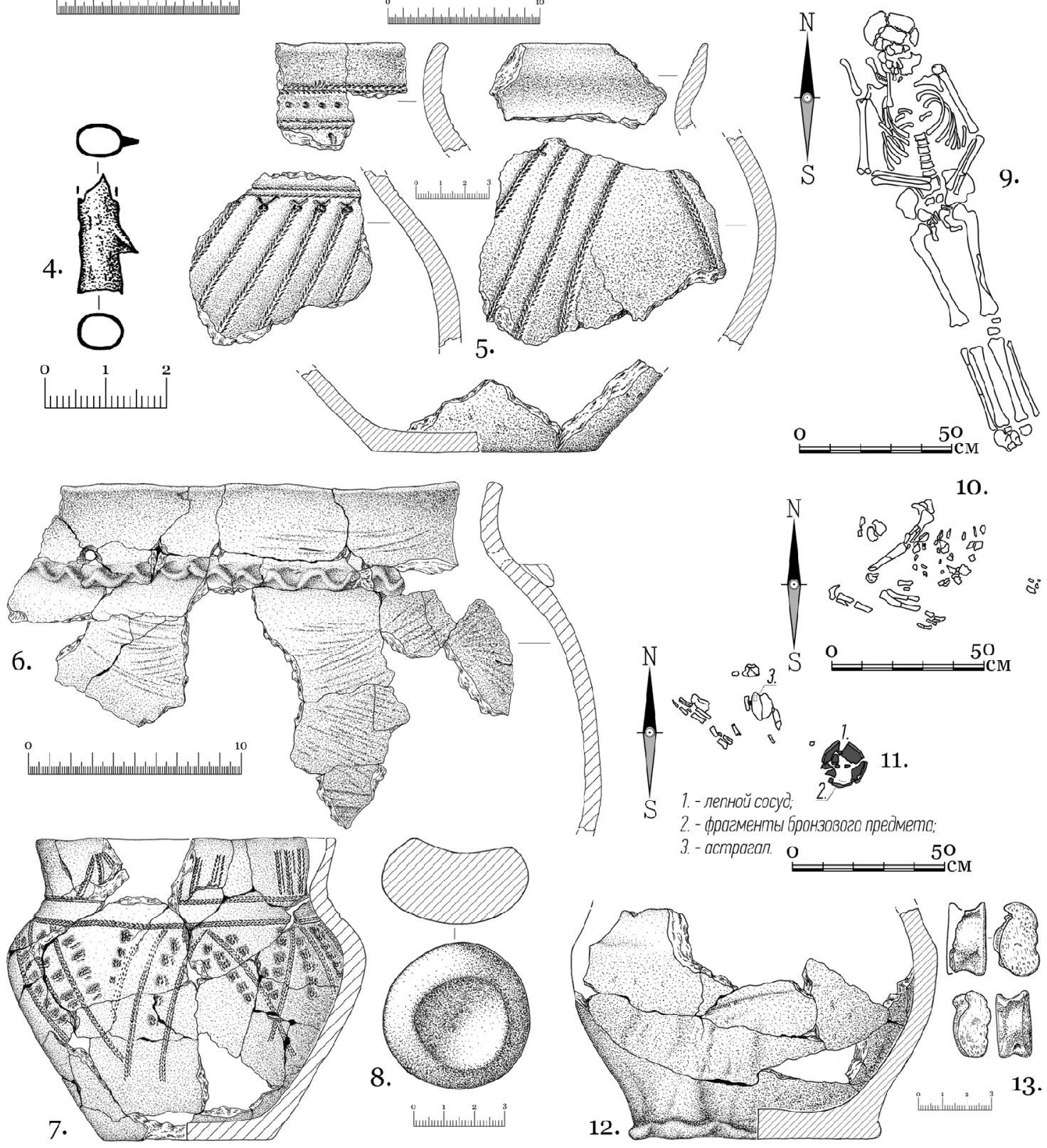

Рис. 2. Курганный могильник «Мокрый IV», курган 1:

1 - ситуация $2 ; 2$ - ситуация $3 ; 3$ - ситуация $12 ; 4$ - ситуация $10 ; 5$ - ситуация $14 ; 6-8$ - ситуация 15 ; 9 - план погребения $1 ; 10$ - план погребения $2 ; 11$ - план погребения $3 ; 12-13$ - инвентарь погребения 3

Fig. 2. Mokryy IV burial mound, barrow 1 :

1 - situation $2 ; 2$ - situation $3 ; 3$ - situation $12 ; 4$ - situation $10 ; 5$ - situation $14 ; 6-8$ - situation 15 ;

9 - plan of burial $1 ; 10$ - plan of burial $2 ; 11$ - plan of burial $3 ; 12-13$ - funeral equipment of burial 3 


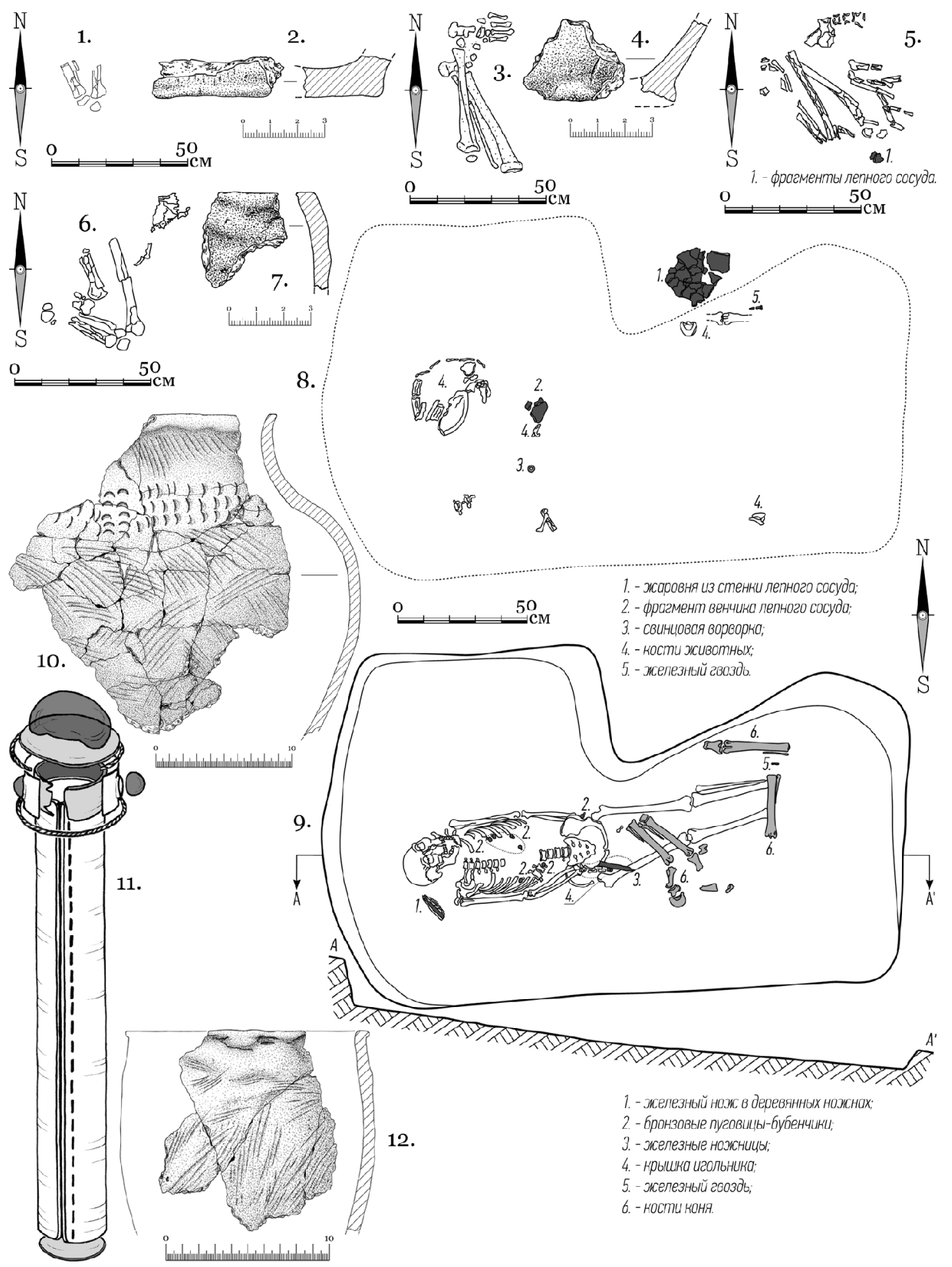

Рис. 3. Курганный могильник «Мокрый IV», курган 1:

1 - план погребения 4; 2 - инвентарь погребения 4; 3 - план погребения 5; 4 - инвентарь погребения 6; 5 - план погребения 6; 6 - план погребения 7; 7 - инвентарь погребения 7;

8 - план погребения 8 на верхнем уровне фиксации; 9 - план погребения 8 на нижнем уровне фиксации; 10,12 - инвентарь погребения 8 с верхнего уровня фиксации; 11 - реконструкция игольника из погребения 8

Fig. 3. Mokryy IV burial mound, barrow 1:

1 - plan of burial 4; 2 - funeral equipment of burial $4 ; 3$ - plan of burial $5 ; 4$ - funeral equipment of burial 6 ; 5 - plan of burial $6 ; 6$ - plan of burial $7 ; 7$ - funeral equipment of burial 7 ;

8 - plan of burial 8 on the upper level of fixation; 9 - plan of burial 8 on the lower level of fixation;

10,12 - funeral equipment of burial 8 from the upper level of fixation; 11 - reconstruction of the needle case from burial 8 

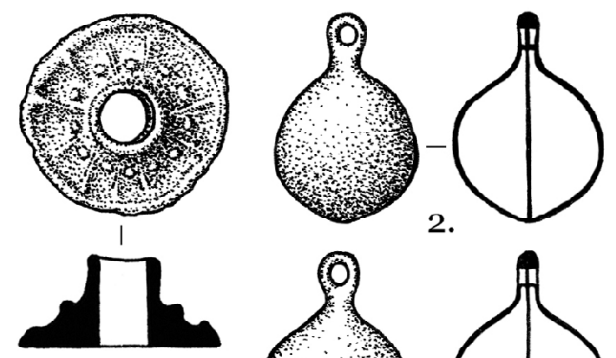

1.
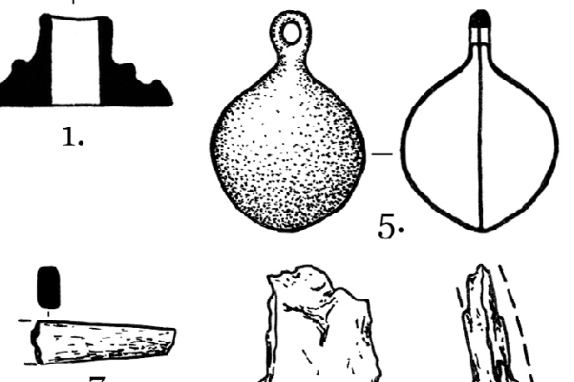

7.
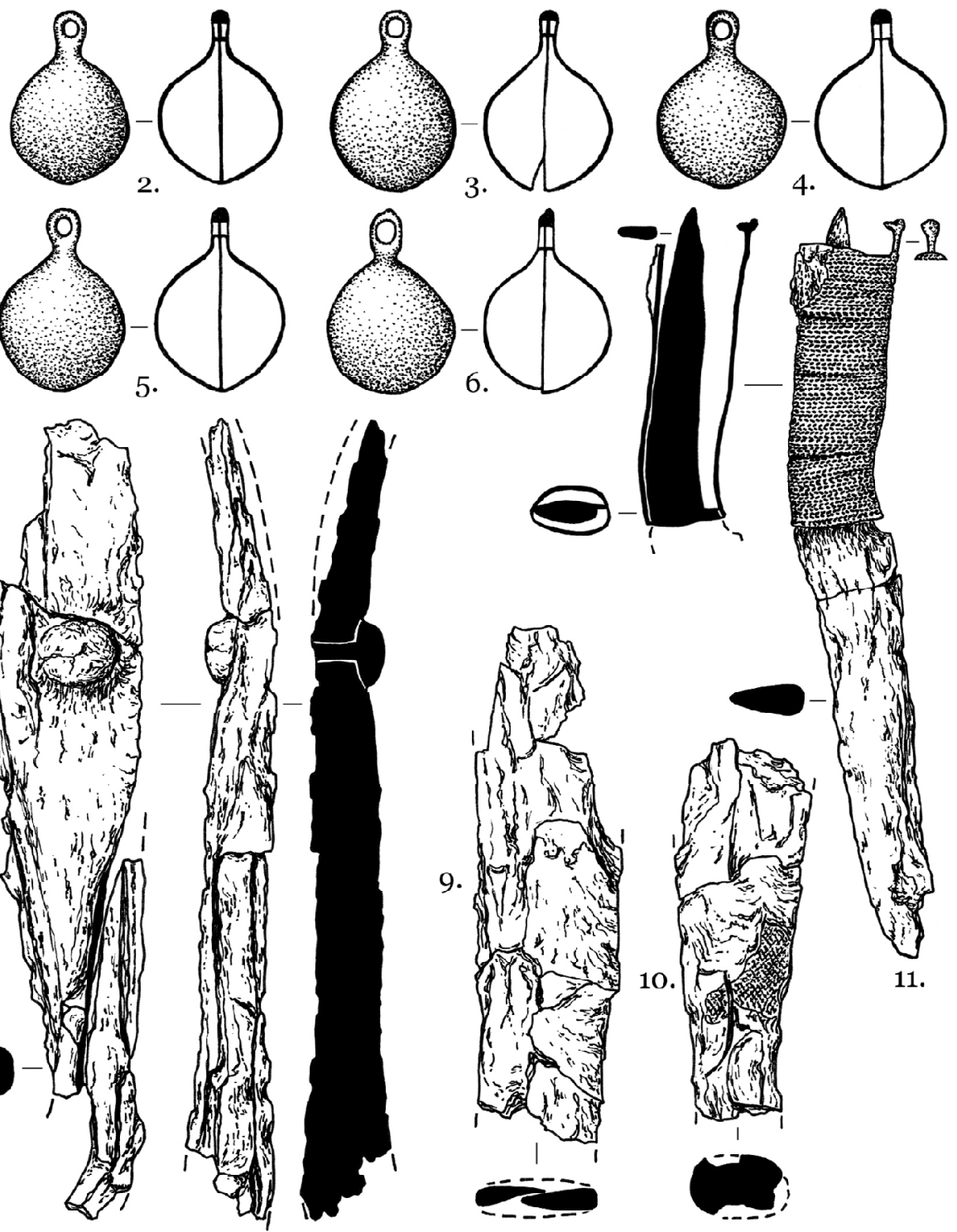

6.
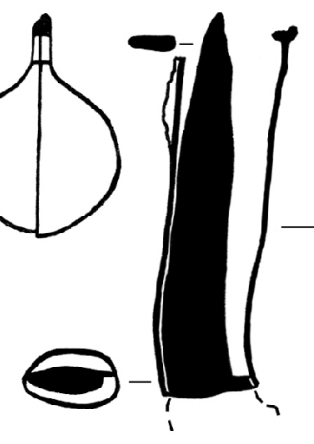

9.

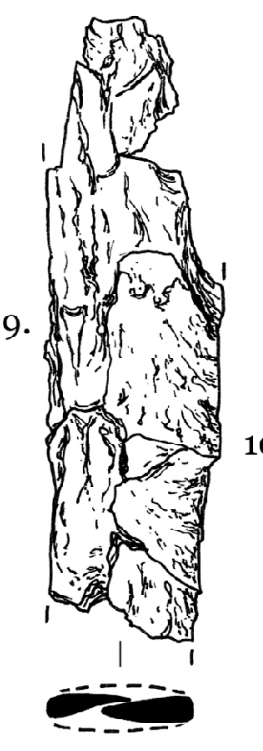

10.

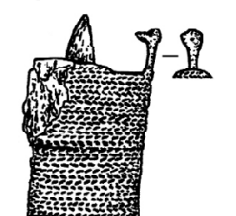

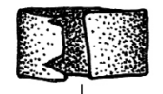
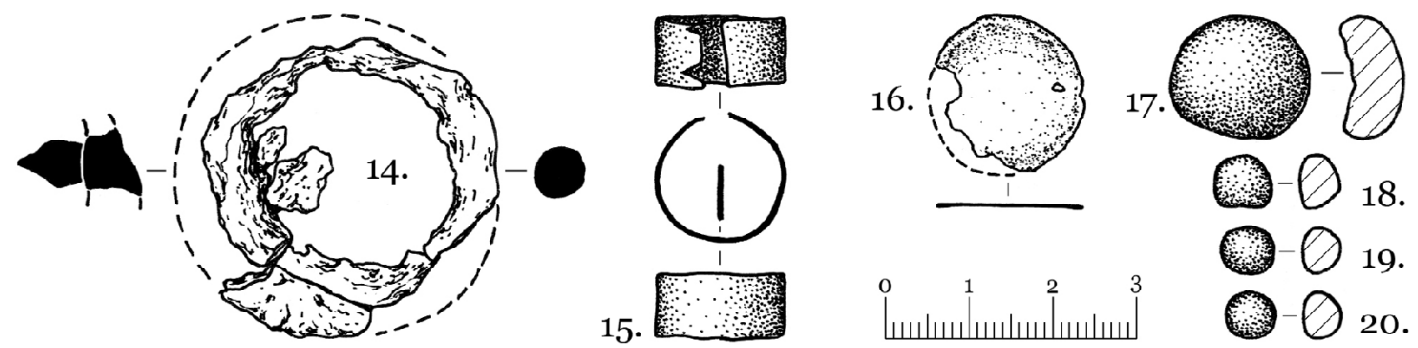

Рис. 4. Курганный могильник «Мокрый IV», курган 1, погребение 8, инвентарь с нижнего уровня фиксации:

1 - свинцовая ворворка; 2-6 - бронзовые пуговицы-«бубенчики»; 7 - черешок железного ножа;

8-10 - фрагменты железных ножниц; 11 - железный нож с серебряной оплеткой рукояти;

12-13 - фрагменты железных гвоздей; 14 - фрагмент железных удил; 15 - бронзовая обойма; 16 - бронзовая пластина; 17-20 - стеклянные вставки

Fig. 4. Mokryy IV burial mound, barrow 1, burial 8, funeral equipment from the lower level of fixation:

1 - lead vorvorka; $2-6$ - bronze buttons-small closed bells; 7 - iron knife shaft;

8-10 - iron scissors fragments; 11 - iron knife with silver wire wrapped handgrip;

12-13 - iron nails fragments; 14 - fragment of iron bits; 15 - bronze clip;

16 - bronze plate; $17-20$ - glass insets 

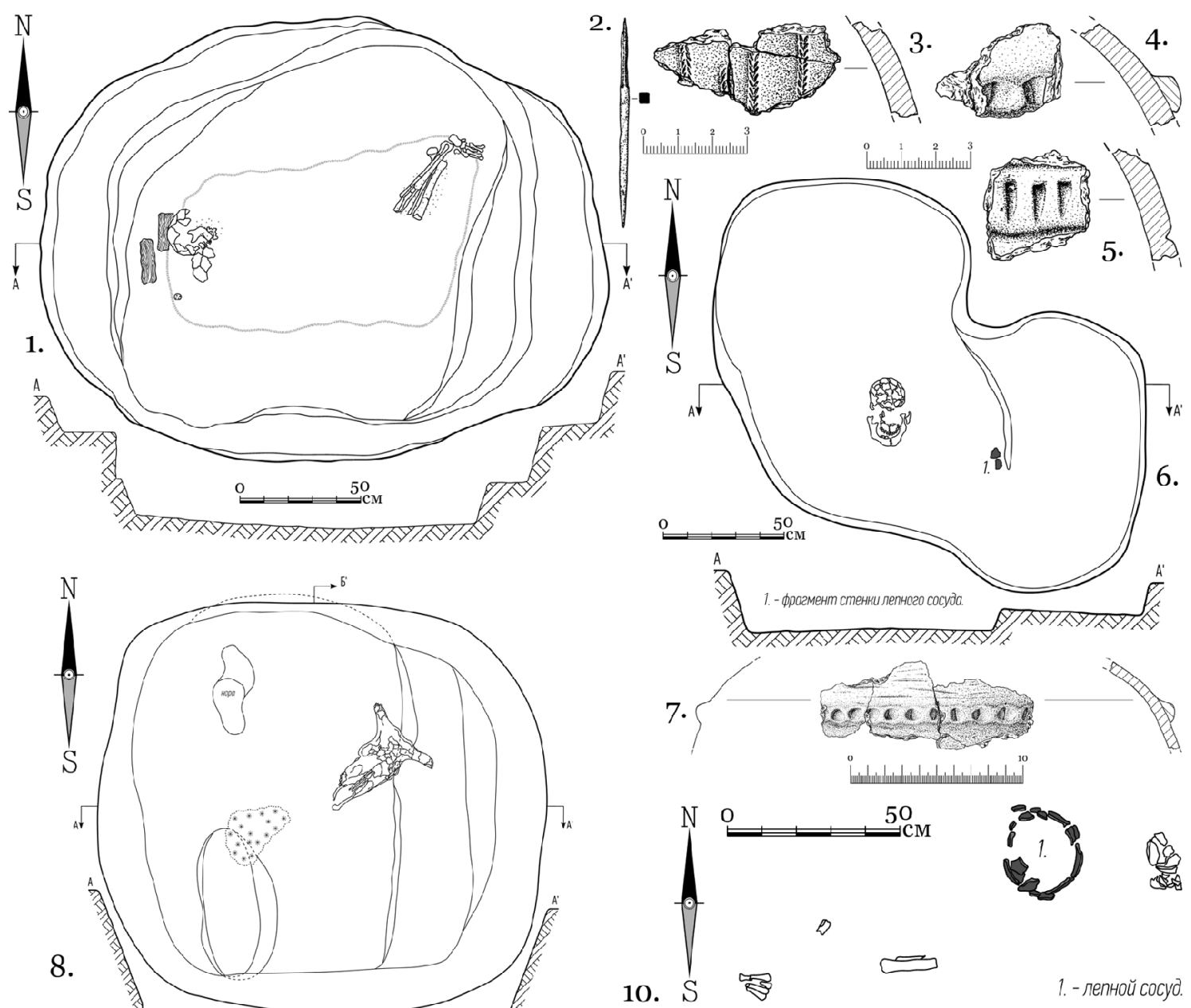

8.
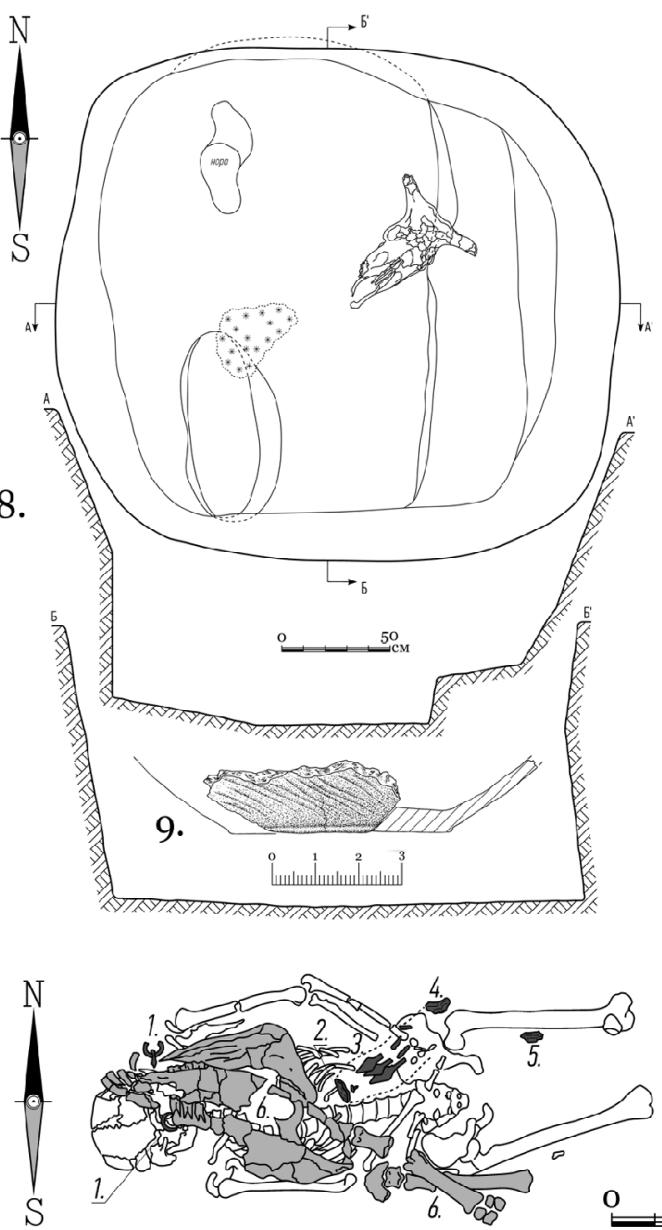

12.

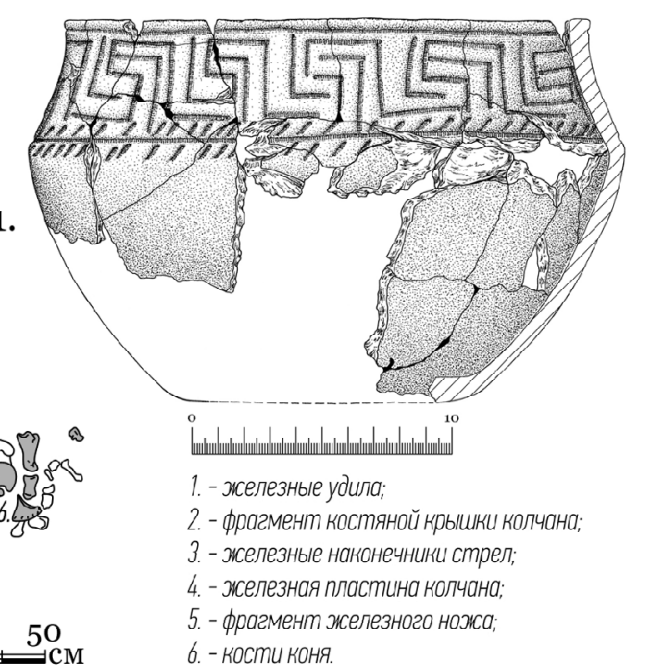

Рис. 5. Курганный могильник «Мокрый IV», курган 1:

1 - план погребения 9; 2-3 - инвентарь погребения 9; 4-5, 7 - инвентарь погребения 10 ;

6 - план погребения $10 ; 8$ - план погребения $11 ; 9$ - инвентарь погребения $11 ; 10$ - план погребения 12 ;

11 - инвентарь погребения 12; 12 - план погребения 13

Fig. 5. Mokryy IV burial mound, barrow 1:

1 - plan of burial 9; 2-3 - funeral equipment of burial 9; 4-5, 7 - funeral equipment of burial 10;

6 - plan of burial $10 ; 8$ - plan of burial $11 ; 9$ - funeral equipment of burial $11 ; 10$ - plan of burial 12 ;

11 - funeral equipment of burial 12;12 - plan of burial 13 
Р.В. Прокофьев, T.E. Прокофьева. Курганный могильник «Мокрый IV»

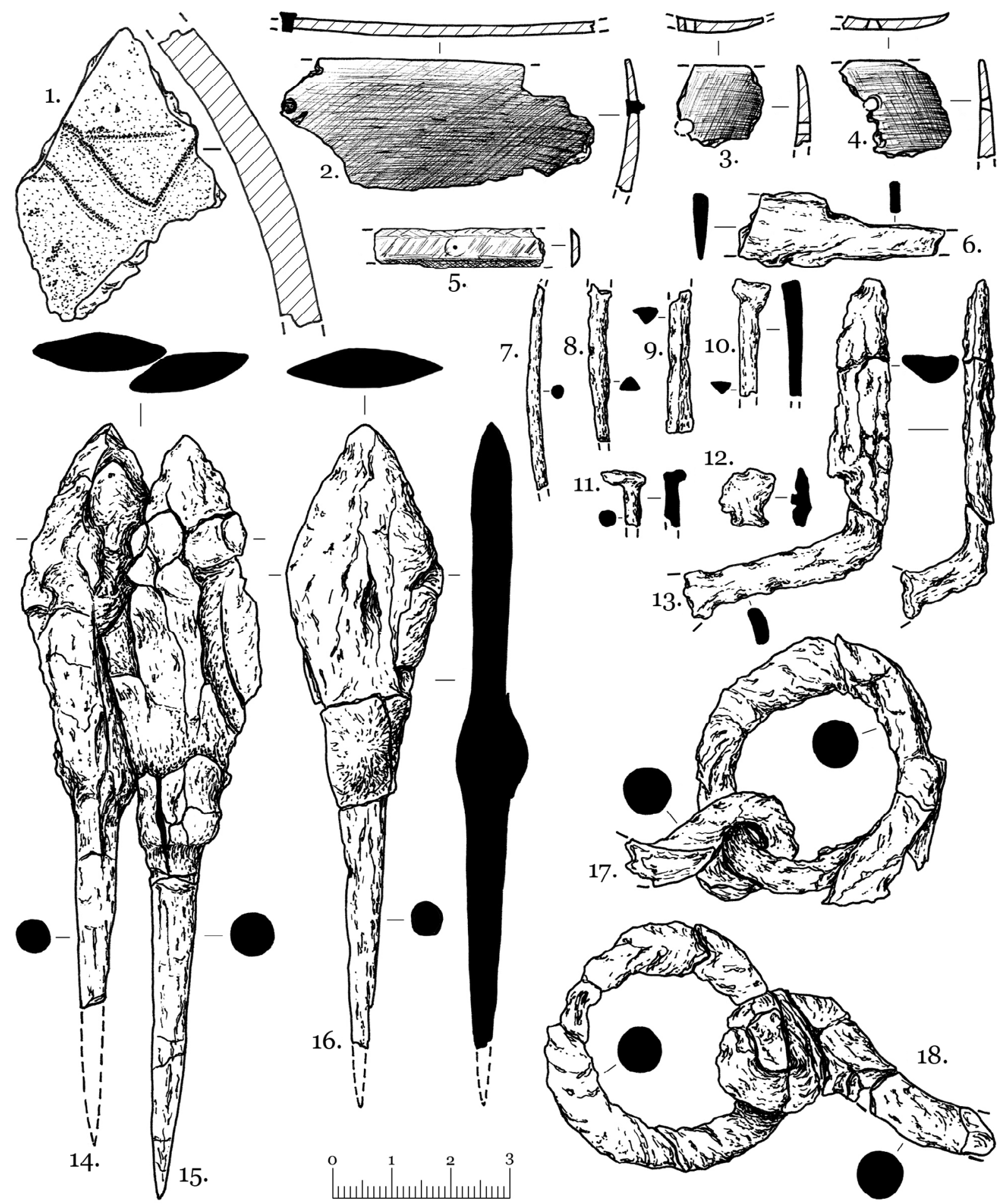

Рис. 6. Курганный могильник «Мокрый IV», курган 1, инвентарь погребения 13:

1 - фрагмент лепного сосуда; 2-5 - фрагменты костяных обкладок колчана; 6 - фрагмент железного ножа;

7-13 - фрагменты железных деталей колчана; 14-16- железные наконечники стрел; 17-18- фрагменты железных удил

Fig. 6. Mokryy IV burial mound, barrow 1 , funeral equipment of burial 13:

1 - fragment of hand-made vessel; $2-5$ - quiver bone plates fragments; 6 - fragment of iron knife;

7-13- quiver iron details fragments; $14-16$ - iron arrowheads, $17-18$ - iron bits fragments 


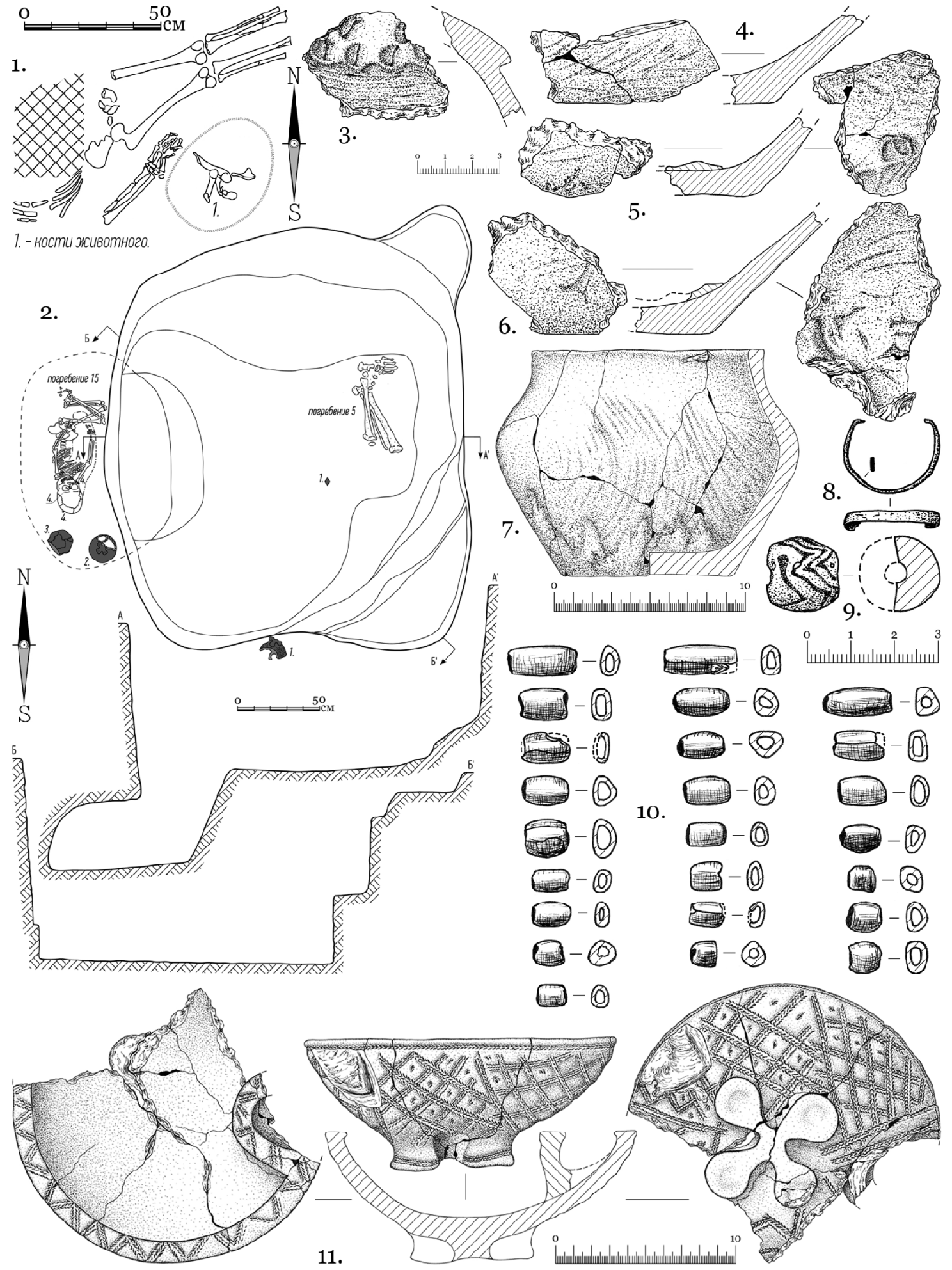

Рис. 7. Курганный могильник «Мокрый IV», курган 1:

1 - план погребения 14; 2 - план погребения 15; 3-11- инвентарь погребения 15 (3-6- фрагменты реповидного сосуда; 7 - лепной сосуд; 8 - дужка бронзового перстня, 9 - полихромная стеклянная бусина, 10 - костяные пронизи, 11 - лепная курильница)

Fig. 7. Mokryy IV burial mound, barrow 1:

1 - plan of burial 14; 2 - plan of burial 15;3-11 - funeral equipment of burial 15 (3-6 - fragments of repovidnyy vessel, 7 - hand-made vessel, 8 - fragment of bronze finger-ring, 9 - polychrome glass bead, 10 - bone beads, 11 - hand-made censer) 


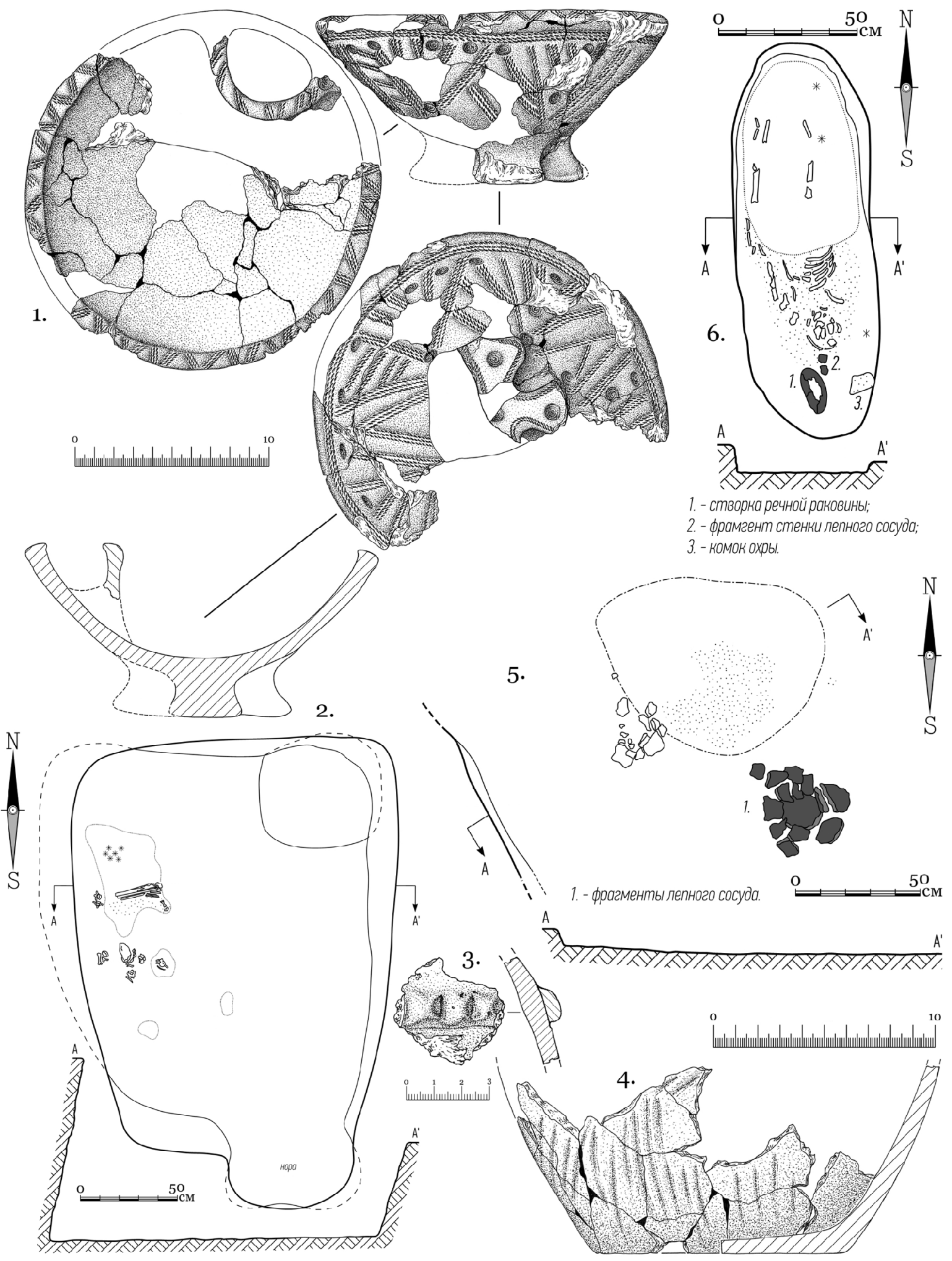

Рис. 8. Курганный могильник «Мокрый IV», курган 1 :

1 - лепная курильница погребения $15 ; 2$ - план погребения $16 ; 3$ - инвентарь погребения 16 ; 4 - инвентарь погребения 17; 5 - план погребения 17; 6 - план погребения 18

Fig. 8. Mokryy IV burial mound, barrow 1 :

1 - hand-made censer from burial 15;2 - plan of burial 16;3 - funeral equipment of burial 16; 4 - funeral equipment of burial 17;5-plan of burial 17; 6 - plan of burial 18 


\section{ПРИМЕЧАНИЯ}

${ }^{1}$ Все остеологические и антропологические определения выполнены старшим научным сотрудником Азовского историко-археологического и палеонтологического музея-заповедника, кандидатом биологических наук Е.Ф. Батиевой.

2 Здесь и далее при описании сосудов приняты следующие сокращения: ДВ - диаметр венчика, $Д^{\mathrm{T}}$ - максимальный диаметр тулова, Дम - диаметр дна, Н-высота.

\section{СПИСОК ЛИТЕРАТУРЫ}

Алексеева Е. М., 1978. Античные бусы Северного Причерноморья. М. : Наука. 105 с.

Гарустович Г. Н., Иванов В. А., 2001. Огузы и печенеги в евразийских степях. Уфа: Гилем. 212 с.

Гудименко И. В., Цыбрий Л. А., 2011. Отчет об археологических работах на объекте культурного наследия курганном могильнике «Мокрый IV», курган № 2, расположенном в Октябрьском районе Ростовской области // Архив НП «Южархеология». $31 \mathrm{c}$.

Круглов Е. В., 2001. Погребальный обряд огузов Северного Прикаспия 2-й пол. IX - 1-й пол. XI в. // Степи Европы в эпоху средневековья. Т. 2. Донецк : ДонНУ. С. 395-446.

Круглов Е. В., 2003. Печенеги и Огузы: некоторые проблемы археологических источников // Степи Европы в эпоху средневековья. Т. 3. Донецк : ДонНУ. С. 13-82.

Плетнева С. А., 1959. Керамика Саркела - Белой Вежи // МИА. № 75. Труды Волго-Донской археологической экспедиции. Т. II. М. ; Л. : Изд-во АН СССР. С. 212-272.

Плетнева С. А., 1963. Кочевнический могильник близ Саркела - Белой Вежи // Материалы и иссле- дования по археологии СССР. № 109. Труды Волго-Донской археологической экспедиции. Т. III. М. ; Л. : Изд-во АН СССР. С. 216-259.

\section{REFERENCES}

Alekseeva E.M., 1978. Ancient beads of the North Pontic Region. Moscow, Nauka Publ. 105 p. (in Russian).

Garustovich G.N., Ivanov V.A., 2001. Oguz and Pecheneg tribes in Eurasian steppes. Ufa, Gilem Publ. 212 p. (in Russian).

Gudimenko I.V., Tsybriy L.A., 2011. The report on the archaeological work on the cultural heritage object - Mokryy IV burial mound, barrow 2, located in Oktyabrskiy district of the Rostov region. Archive of NP "Yuzharkheologiya". 31 p. (in Russian).

Kruglov E.V., 2001. Funeral rite features of the Oguz tribe from the North Caspian Lowlands of the $2^{\text {nd }}$ half of the $9^{\text {th }}-$ first half of the $11^{\text {th }} \mathrm{cc}$. Steppes of Europe in the Middle Ages. Vol. 2. Donetsk, DonNU Publ., pp. 395-446. (in Russian).

Kruglov E.V., 2003. Pecheneg and Oguz tribes: Certain problems of archaeological sources. Steppes of Europe in the Middle Ages. Vol. 3. Donetsk, DonNU Publ., pp. 13-82. (in Russian).

Pletneva S.A., 1959. Pottery of Sarkel - Belaya Vezha. Materials and research on the archaeology of the USSR, no. 75. Works of the Volga-Don archaeological expedition. Moscow; Leningrad, Izd-voAN SSSR, pp. 212-272. (in Russian).

Pletneva S.A., 1963. Nomadic burial mound near Sarkel - Belaya Vezha. Materials and research on the archaeology of the USSR, no. 109. Works of the Volga-Don archaeological expedition, vol. III. Moscow; Leningrad, Izd-vo AN SSSR, pp. 216-259. (in Russian).

\section{Information about the Authors}

Roman V. Prokofyev, Researcher, Centre for Practical Archaeology, Prosp. Budennovskiy, 93/295, office 29, 344030 Rostov-on-Don, Russian Federation, romaprok@mail.ru.

Tatyana E. Prokofyeva, Researcher, Centre for Practical Archaeology, Prosp. Budennovskiy, 93/295, office 29, 344030 Rostov-on-Don, Russian Federation, hahatanja@yandex.ru.

\section{Информация об авторах}

Роман Викторович Прокофьев, научный сотрудник ООО «Центр Практической Археологии», просп. Буденновский, 93/295, оф. 29, 344030 г. Ростов-на-Дону, Российская Федерация, romaprok@mail.ru.

Татьяна Евгеньевна Прокофьева, научный сотрудник ООО «Центр Практической Археологии», просп. Буденновский, 93/295, оф. 29, 344030 г. Ростов-на-Дону, Российская Федерация, hahatanja@yandex.ru. 